\title{
Factors Affecting Employee Satisfaction in the Private Organizations of Bahawalpur Pakistan
}

\author{
Muhammad Ahsan Awan \\ Department of Management Sciences, The Islamia University of Bahawalpur, Pakistan \\ E-mail piscesawan@gmail.com
}

Muhammad Rizwan

Lecturer, Department of Management Sciences

The Islamia University of Bahawalpur, Pakistan

Email: rizwan.arshad@iub.edu.pk

Junaid Bin Razzaq

Department of Management Sciences, The Islamia University of Bahawalpur, Pakistan

E-mail razzaq.junaid@ymail.com

\section{Usman Ali}

Department of Management Sciences, The Islamia University of Bahawalpur, Pakistan

E-mail usman.jalandri@gmail.com

Doi:10.5296/ ijhrs.v4i2.5904 URL: http://dx.doi.org/10.5296/ ijhrs.v4i2.5904

\begin{abstract}
Research was conducted to analyze the effect of empowerment, rewards, training \& development and working conditions on employee satisfaction and also the impact of top level management on all these variables. The aim of this study was to find out the degree of satisfaction level of employees and the behavior of top level management in suffocated conditions in the developing city of Islamic Republic Pakistan. For this purpose 200 questionnaires were distributed from which 160 were got back and 151 were selected to examine and analysis. It was found after analysis that only rewards has positive significant effect on worker, rest of the variables showed insignificant effect on employee satisfaction. The top level management had the positive significant effect on rewards, training \& development and empowerment.
\end{abstract}

Keywords: Empowerment, Rewards, Training \& Development, Working Conditions 


\section{Introduction}

As there are lot of researches, but there is no specific description about employee satisfaction. Every scholar and researcher describes employee satisfaction according to their perspective and siege. Before exploring employee satisfaction, it is necessary to know about the importance of vigorous action of human activities should be carefully realized. Employee satisfaction is a phrase used to explain how much an employee is happy and calm in his job. Employee satisfaction is a circumstance in an employee enthusiasm, employee goal achievement and positive morale in the particular work place (Susan M Heath Field). Furthermore Hoppock (1935) describes employee satisfaction, the blend or set or collection of psychological, physiological and external factors such as surroundings or environment that compels a person to say honestly that he is happy from his job. According to this approach even though employee satisfaction is under the influence of many external factors, but it remains something internal that has to do with the way that how the employee feels. Employee satisfaction gives collection of positive and negative feelings that employee have towards their job. According to Davis et al 1985 Employee Satisfaction is the combination of expectations which synchronize with the real world or it is the synchronization of one's ideal world with the real world.

Now a day's world is continuously changing and everyone knows about his or her rights, so today researchers and human resource managers paying special attention in this area to know about that factors which lead to the employee satisfaction at their job environment (Igalens and Rousch, 1999). In this era of competition every employer is thinking to know the satisfactory level of employee. According to Spector 1997 Employee Satisfaction is how a person takes his job and what his feeling about his job is. Ophara, 2002 discussed employee satisfaction a result of different circumstances e.g. salary, appreciation, the job itself and the behavior with the colleagues. In 2004 Frye discussed that fair appreciation and performance are directly proportional to employee satisfaction. In 2003 Park et al discovered that if you want to give development to your organization, than organization must give the equity based appreciations and compensations to their employees.

Many researchers came and give their point of view about satisfaction of an employee Mr. Robert et al in 2010 discussed employee satisfaction in advanced level and gave the idea of employee satisfaction, according to researcher the major terms which lead to employee satisfaction are employee empowerment, training \& development, rewards, working conditions, working environment, power on job, self authority, equity based performance evaluation all are key points to accelerate employees satisfaction.

The purpose of this paper is to check the degree of employee satisfaction under these variables, Hales and Klidas 1998 described empowerment as the sharing of knowledge, information and power to the employees by the employers. According to Cunningham et al 1996, the dedication of decision making power to the employees, that the employee can take decision on his behalf without any hesitation and giving trouble to their employers.

Rewards are the benefits other than salary given to employees on their hard work, on their efficiency or to increase their morale and confidence in the organization. According to 


\section{Macrothink}

International Journal of Human Resource Studies

ISSN 2162-3058

2014, Vol. 4, No. 2

Ngvyen et al (2003) Employee satisfaction is the outcome of promotion opportunities in the organization.

Training is the process of polishing and enhancing the beauty of skills and updates the employee's skills according to the advanced techniques, that an employee will be able to adopt the changes and face the technical challenges in the organization. Silla et al (2005) and Ceyclen (1998) discovered that working conditions have strong impact on the satisfaction level of employees. Working conditions are consists of technology, good staff, neat and clean environment etc.

\section{Literature Review and Hypotheses}

In this section we provide a brief literature review of the concepts used in our research, which leads to the development of our hypotheses.

Locke 1969 described that employee satisfaction is the comparison between one's expectations and what he is getting from his job. Again in 1976 Locke said employee satisfaction is that state of positive emotional factor excluding from the evaluation of one's work experience. In 1997Spector defines that employee satisfaction is the extent to which employee feels happy or unhappy from his job. In 1993 Schermerhon says that the response of an employee towards different directions of the work. C.R Reily 1991 defined employee satisfaction that the mentality of an employee towards his job that what does he think about his job and what is his feeling (good or bad). Hussami 2008 said that employee satisfaction doesn't only rely on nature of job but it also rely on what are the expectations of an employee, that what is his thinking and what does he want from his job and organization.

We can conclude from discussions that employee satisfaction is the observing and thinking reflections of a particular employee.

\subsection{Employee Satisfaction Factors}

There are many factors which make an employee satisfy or dissatisfy from his job. These factors are differing from one employee to the other employee and from day to day activities (Chum Lo and Ramayah, 2011). The manager must know about the needs of worker to achieve the high level of employee's satisfaction (Locke, 1976).

Factors affecting employee satisfaction are;

- Rewards

- Working conditions

- Empowerment

- Training \& Development

\subsubsection{Impact of rewards on Employee Satisfaction}

Employee satisfaction is a fruit of various factors like pay, promotion, appreciation, compensation and equity based evaluation (Ophara, 2002). In 2004 Frye found that there is 
direct relationship between fair compensation and performance. It was concluded that compensation plays crucial role in the satisfaction level of employee. Park et al (2003) discussed further that if organization wants to achieve goals and enhance the performance of employees than equity based compensation should be given to employees. Employee satisfaction is the outcome of promotion opportunities in the organization (Ngvyen et al, 2003).

From the above discussion we propose the following hypothesis:

H1: Reward has positive impact on Employee Satisfaction

\subsubsection{Impact of Empowerment on Employee Satisfaction}

Empowerment plays important role in employee satisfaction, but still there is no single dimensional definition of empowerment ( Peccei an Rosenthal, 2001). According to Hales and Klidas, Empowerment is a dedication of powers to employees by the employers. Cunninghm et ak (1996) furthermore said the capability of an employee to take decisions on his behalf is called empowerment. Thomas (1990) discovered that empowerment is not limited in one direction but it is the internal enthusiasm which is the blend of sense, competence, choice and impact. Employee empowerment is considered as to accelerate the satisfaction level of an employee. In $2010 \mathrm{He}$ et al proved that employee empowerment has positive relation on Employee Satisfaction.

So from above discussion we concluded that:

H2: Empowerment has positive Impact on Employee Satisfaction

\subsubsection{Impact of Training and Development on Employee Satisfaction}

Employee training gives chance to employees to enhance their capability and competency to gain individual development (Jun et al. 2006). Sakes (1996) said that those employees who are well trained are not equal to those who are not trained and both have different level of satisfaction; the trained employee will be more satisfy than non trained employee. Martensen \& Gronholdt (2001) discovered that there is positive significant affect of training on employee satisfaction. When an organization held training programs than their employees think that company is investing on us and they want to polish our skills, due to this they get opportunity of development and progress (Jun et al, 2006; Rizwan et al., 2013).

As a result of above discussion we developed a hypothesis:

H3: Training \& Development has positive Impact on Employee Satisfaction

\subsubsection{Impact of Working Conditions on Employee Satisfaction}

Employee satisfaction mentions to the degree at which the working conditions meets the expectations and needs of employee. The ingredients of working conditions are work itself, social interaction with co workers, physical environments and the relation between these actors. Working environment is an important factor of employee satisfaction (Herzberg, 1968, Spector, 2008). Guest (2004), Silla et al (2003) concluded that the working conditions has 


\section{Macrothink}

International Journal of Human Resource Studies

ISSN 2162-3058

2014, Vol. 4, No. 2

significant affect on employee satisfaction. It includes temperature, lighting, ventilation etc.

It supports following hypothesis:

H4: Working Conditions has positive impact on Employee Satisfaction

\section{Top Level Management}

Top Level Management plays a vital role in a particular organization and it is considered to be one of the important rules of total quality management because of their relationship with employee satisfaction (Kofi, 2000; Rizwan et al., 2013). Researchers discovered that there is a positive relationship between top level management to empowerment, rewards, training and development.

\subsubsection{Impact of Top Level Management on Rewards}

If the organization do justice with employees and conduct equity based compensation then the employee will be happy from his organization and he will try to give his best to the particular organization. Due to this he will be more loyal for his company and his satisfaction level will be match to his expectation (Frye, 2004). Rewards are the cash or non cash benefits provided by the employer to the employees (ACA,p.9). So according to above discussion we are going to develop the hypothesis that:

H5: Top level Management has positive Impact on Rewards

\subsubsection{Impact of Top Level Management on Empowerment}

The primary objective of empowerment is to give the employees the power of decision making that employees can take decisions on their behalf and there will be no restrictions on them. Many researchers believe that organization can accelerate and improve their productivity through empowerment (Hales and Klidas). From this discussion we develop the hypothesis:

H6: Top Level Management has positive Impact on Empowerment

\subsubsection{Impact of Top Level Management on Training \& Development}

Training means that how much organization is investing to teach and enhance the beauty of the skills of their employees and it is the continuous process of making the employees effective and efficient according to time, development means the career achievement in future. Training compels the employees to do their work efficiently and effectively. This will lead to positive relationship between Top Level Management and employees because due to this employee will perceive their superiors as responsible for their employees. This thing will force the employee to work according to the demand of their superiors Silla et al (2005) and (Jun et al, 2006).

So we concluded that

H7: Top Level Management has positive relationship on training \& Development 


\section{Macrothink}

\section{Proposed Modal}

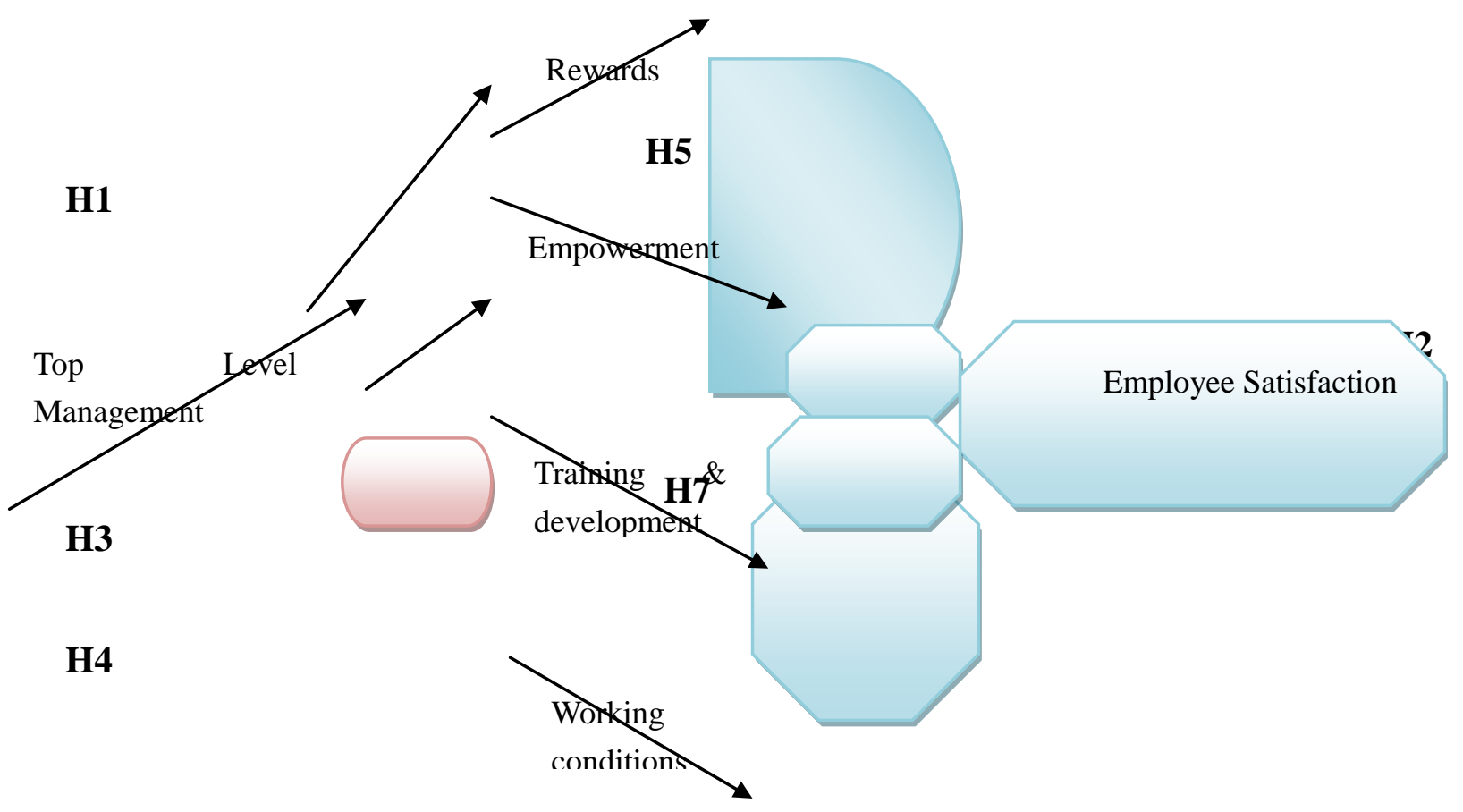

\section{Research methodology}

The current study is descriptive in nature. Descriptive research can be defined as to explore something or to describe the specific circumstances. According to Cresswell (1994) descriptive researches are those researches, which study the already existing problems instead of drawing conclusion and results. The main objective of the descriptive research is verification of the developed hypothesis that reflects the current situation. This type of research provides information about the current scenario and focus on past or present for example quality of life in a community or customer attitudes towards any marketing activity (Kumar, 2005).

\subsection{Sample Data}

In order to collect the data for understanding the situation about the satisfaction level of an employee in the private organization, a sample of 200 respondents will ask to participate in a self-administered questionnaire. The population for the current research is the employees of private organizations working in Bahawalpur Pakistan.

\subsection{Instruments and Measures}

The survey instrument of the current study address two major purposes: First is to analyze the relationship of different variables in the adoption of employee satisfaction. Second, to collect information about the different characteristics of the respondents that can be used to understand the variations in different categories.

The survey instrument contains two sections. Section I includes different personal and demographic variables. This section will obtain the respondent's information about gender, 


\section{Macrothink}

age, income and organization. This section of study is developed based on the past literature and already used questionnaires (Table 1)

The scales of the study were adopted from the previous literature and published studies. The first variable is employee satisfaction contains 7 items and these scales were taken from Churchill et al. (1974). The second variable is Reward contains 4 item were taken from RoshanLevin Roberts (2005). The third variable is Working conditions contains 3 items, were taken from Roshan Levina Roberts (2005). The fourth variable is Empowerment that contains 4 items and was taken from Hackman and Oldham, (1975). The fifth variable is Training \& Development contains 5 items, were taken from Lee (2005). The last and sixth variable is Top Management Leadership having 4 items and were taken from Ugboro, K Obeng (2000).

TABLE 1:

\begin{tabular}{|c|c|c|c|}
\hline \# & Variables & Items & References \\
\hline 1 & $\begin{array}{l}\text { Employee } \\
\text { satisfaction }\end{array}$ & $\begin{array}{l}\text { 1. I find my work very satisfying } \\
\text { 2. I feel that I am really doing something worthwhile in } \\
\text { my job. } \\
\text { 3. My work is challenging } \\
\text { 4. My job is very interesting. } \\
\text { 5. My work gives me a sense of accomplishment } \\
\text { 6. My work is very creative } \\
\text { 7. My job is often dull and repetition. }\end{array}$ & $\begin{array}{ll}\text { Churchill et } \\
\text { al. (1974). }\end{array}$ \\
\hline 2 & Reward & $\begin{array}{l}\text { 1. My salary is satisfactory in relation to what I do. } \\
\text { 2. I earn the same as or more that other people in a } \\
\text { similar job. } \\
\text { 3. The basis of payment, for example overtime } \\
\text { payment, is reasonable. } \\
\text { 4. Salary increases are decided on a fair manner. }\end{array}$ & $\begin{array}{l}\text { RoshanLevina } \\
\text { Roberts } \\
(2005)\end{array}$ \\
\hline 3 & $\begin{array}{l}\text { Working } \\
\text { Condition }\end{array}$ & $\begin{array}{l}\text { 1. My working hours are reasonable. } \\
\text { 2. I am never overworked. } \\
\text { 3. I get the opportunity to mix with my colleagues and } \\
\text { to communicate on aspects of our work. }\end{array}$ & $\begin{array}{l}\text { RoshanLevina } \\
\text { Roberts } \\
(2005)\end{array}$ \\
\hline
\end{tabular}




\begin{tabular}{|c|c|c|c|}
\hline 4 & Empowerment & $\begin{array}{l}\text { 1. I have the authority to correct customer } \\
\text { problems when they occur. } \\
\text { 2. I am encouraged to handle customer problems } \\
\text { by myself. } \\
\text { 3. I have control over how I solve customer } \\
\text { problems. } \\
\text { 4. I am able to control the social contact with } \\
\text { others around me. }\end{array}$ & $\begin{array}{l}\text { Hackman and } \\
\text { Oldham, } \\
(1975)\end{array}$ \\
\hline 5 & $\begin{array}{l}\text { Training and } \\
\text { Development }\end{array}$ & $\begin{array}{l}\text { 1. My company provides me the opportunity to } \\
\text { improve my skills } \\
\text { 2. There is lot of chance to learn new things in } \\
\text { this company } \\
\text { 3. My company frequently arranges training } \\
\text { programs for the employees } \\
\text { 4. Doing job in this company will benefit me in } \\
\text { the future } \\
\text { 5. I am satisfied with the training and } \\
\text { development provided by the company }\end{array}$ & Lee (2005) \\
\hline 6 & $\begin{array}{l}\text { Top } \\
\text { Management } \\
\text { Leadership }\end{array}$ & $\begin{array}{l}\text { 1. Top management has devised credible reward } \\
\text { systems that recognize employee and managers } \\
\text { for the quality achievement. } \\
\text { 2. Necessary policy changes have been made to } \\
\text { encourage employees; participation and } \\
\text { involvement in TQM process. } \\
\text { 3. Top management provides needed funds for } \\
\text { equipment. } \\
\text { 4. Top management provides necessary funds to } \\
\text { train employees on the essential TQM } \\
\text { techniques. }\end{array}$ & $\begin{array}{l}\text { Ugboro, } \quad \text { K } \\
\text { Obeng (2000) }\end{array}$ \\
\hline
\end{tabular}

\subsection{Procedure}

The questionnaire was distributed among 200 respondents in Bahawalpur. These respondents 
are selected based on the criteria above mentioned. Before giving the questionnaire, the purpose of the study and questions were explained to respondents so they can easily fill the questionnaires with relevant responses. A total of 151 were selected and rest of the questionnaires was not included in the further analysis due to incomplete or invalid responses. After collecting the completed questionnaires, these questionnaires were coded and entered into SPSS for further analysis.

\subsection{Reliability Analysis}

The Chronbach's alpha of the Employee Satisfaction questionnaire items were more than acceptable and recommended value 0.50 by Nunnally (1970) and 0.60 by Moss et al (1998). This shows that all the items were reliable and valid to measure the opinions of employees towards employee satisfaction.

\section{Table 2:}

\begin{tabular}{|l|l|l|}
\hline Scales & Items & Chronbach Alpha \\
\hline Top level management & 4 & 0.796 \\
\hline Rewards and benefits & 4 & 0.741 \\
\hline Training and development & 5 & 0.824 \\
\hline Empowerment & 4 & 0.768 \\
\hline Working conditions & 3 & 0.526 \\
\hline Employee satisfaction & 7 & 0.733 \\
\hline
\end{tabular}

\section{Results \& Analysis}

\subsection{Profile of the Respondents}

Personal and demographic information such as gender, age, income and organization are presented in table given below. In which we are going to discuss the demographic information of the respondents.

Table 3:

\begin{tabular}{|l|l|l|l|}
\hline Variable & Category & Frequency & Percentage \\
\hline Gender & Male & 96 & 63.6 \\
\hline
\end{tabular}




\begin{tabular}{|l|l|l|l|}
\hline & Female & 55 & 36.4 \\
\hline Age & Below 20 years & 8 & 5.3 \\
& $20-30$ years & 109 & 72.2 \\
$30-40$ years & 32 & 21.2 \\
& Above 40 years & 2 & 1.3 \\
\hline Income & Below Rs. 10000 & 31 & 20.5 \\
& Rs. 10000-20000 & 60 & 39.7 \\
& Rs. 20000-30000 & 37 & 24.5 \\
& Rs. 30000-40000 & 13 & 8.6 \\
& Above Rs. 40000 & 10 & 6.6 \\
\hline \multirow{2}{*}{ Organization } & Private & 151 & 100 \\
\hline
\end{tabular}

\subsection{Hypothesis Testing}

\subsubsection{Impact of Reward on Employee Satisfaction}

According to the results of the study the variable Rewards has significant positive relationship with Employee satisfaction i.e. $($ Beta $=0.300)$ and Significance values is less than 0.05 i.e. 0.002 . So the hypothesis is accepted. It means reward contributes $30 \%$ in employee satisfaction.

\subsubsection{Results of other Hypotheses towards Employee Satisfaction}

The three hypotheses Impact of training and development towards Employee Satisfaction, Impact of empowerment towards Employee Satisfaction and Impact of working Conditions toward Employee Satisfaction are rejected, because their significance value is greater than 0.05 . 
Table 4:

\begin{tabular}{|c|c|c|c|c|c|c|}
\hline \multirow{2}{*}{\multicolumn{2}{|c|}{ Model }} & \multicolumn{2}{|c|}{$\begin{array}{l}\text { Unstandardized } \\
\text { Coefficients }\end{array}$} & \multirow{2}{*}{$\begin{array}{l}\text { Standardized } \\
\text { Coefficients }\end{array}$} & \multirow[b]{2}{*}{$\mathrm{t}$} & \multirow[b]{2}{*}{ Sig. } \\
\hline & & B & Std. Error & & & \\
\hline \multirow[t]{5}{*}{1} & (Constant) & 1.546 & .210 & & 7.346 & .000 \\
\hline & Reward & .197 & .063 & .300 & 3.104 & .002 \\
\hline & Working conditions & -.002 & .067 & -.002 & -.027 & .979 \\
\hline & Empowerment & -.074 & .070 & -.090 & -1.058 & .292 \\
\hline & $\begin{array}{l}\text { Training and } \\
\text { development }\end{array}$ & .089 & .069 & .125 & 1.287 & .200 \\
\hline
\end{tabular}

\subsubsection{Impact of Top Level Management on rewards}

The results shows that there is positive relationship between top level management leadership and rewards i.e. (beta $=0.495$ ) and having significance 0.000 , which is less then recommended 0.05 so this hypothesis is accepted. Top level management contributes above $49 \%$ in rewards.

Table 5:

\begin{tabular}{|c|c|c|c|c|c|}
\hline \multirow[b]{2}{*}{ Model } & \multicolumn{2}{|c|}{$\begin{array}{l}\text { Unstandardized } \\
\text { Coefficients }\end{array}$} & \multirow{2}{*}{\begin{tabular}{|l} 
Standardized \\
Coefficients
\end{tabular}} & \multirow[b]{2}{*}{$\mathrm{t}$} & \multirow[b]{2}{*}{ Sig. } \\
\hline & B & Std. Error & & & \\
\hline (Constant) & 1.429 & .215 & & 6.652 & .000 \\
\hline Top management & .528 & .076 & .495 & 6.962 & .000 \\
\hline
\end{tabular}




\section{Macrothink \\ International Journal of Human Resource Studies \\ ISSN 2162-3058 \\ 2014, Vol. 4, No. 2}

\subsubsection{Impact of top level management on training \& development}

Results shows that there is positive relation between top management and training \& development having $(B e t a=0.601)$ and significance of 0.000 . It is clear that significance is less than 0.05 so it is accepted. Top management contributes above $60 \%$ in training and development.

Table 6:

\begin{tabular}{|c|c|c|c|c|c|c|}
\hline \multirow{2}{*}{\multicolumn{2}{|c|}{ Model }} & \multicolumn{2}{|c|}{$\begin{array}{l}\text { Unstandardized } \\
\text { Coefficients }\end{array}$} & \multirow{2}{*}{\begin{tabular}{|l} 
Standardized \\
Coefficients
\end{tabular}} & \multirow[b]{2}{*}{$\mathrm{t}$} & \multirow[b]{2}{*}{ Sig. } \\
\hline & & B & Std. Error & & & \\
\hline \multirow[t]{2}{*}{$\mid 1$} & (Constant) & .719 & .182 & & 3.941 & .000 \\
\hline & Top management & .591 & .064 & .601 & 9.176 & .000 \\
\hline
\end{tabular}

\subsubsection{Impact of Top level Management on Empowerment}

Results shows that there is positive relationship between Top level Management and Empowerment having (Beta=0.354) and significance of 0.000. As significance is less than recommended 0.05 so it is accepted. Top level Management contributes more than $35 \%$ in Empowerment. As mention in

Table 7:

\begin{tabular}{|c|c|c|c|c|c|}
\hline \multirow[b]{2}{*}{ Model } & \multicolumn{2}{|c|}{$\begin{array}{l}\text { Unstandardized } \\
\text { Coefficients }\end{array}$} & \multirow{2}{*}{\begin{tabular}{|l} 
Standardized \\
Coefficients
\end{tabular}} & \multirow[b]{2}{*}{$\mathrm{t}$} & \multirow[b]{2}{*}{ Sig. } \\
\hline & B & Std. Error & & & \\
\hline (Constant) & 1.387 & .185 & & 7.505 & .000 \\
\hline Top management & .301 & .065 & .354 & 4.617 & .000 \\
\hline
\end{tabular}


Table 8: Regression Results

\begin{tabular}{|c|c|c|c|c|}
\hline Hypotheses & Modal Variables & Beta & Significance & Results \\
\hline H1 & Rewards & 0.300 & 0.002 & Supported \\
\hline H2 & Empowerment & -0.090 & 0.292 & $\begin{array}{l}\text { Not } \\
\text { supported }\end{array}$ \\
\hline H3 & $\begin{array}{ll}\text { Training } & \text { and } \\
\text { development } & \end{array}$ & 0.125 & 0.200 & $\begin{array}{l}\text { Not } \\
\text { supported }\end{array}$ \\
\hline H4 & Working conditions & -0.002 & 9.979 & $\begin{array}{l}\text { Not } \\
\text { supported }\end{array}$ \\
\hline H5 & $\begin{array}{l}\text { Top management and } \\
\text { rewards }\end{array}$ & 0.495 & 0.000 & Supported \\
\hline H6 & $\begin{array}{l}\text { Top management and } \\
\text { empowerment }\end{array}$ & 0.354 & 0.000 & Supported \\
\hline H7 & $\begin{array}{l}\text { Top management in } \\
\text { training and } \\
\text { development }\end{array}$ & 0.601 & 0.000 & Supported \\
\hline
\end{tabular}

\section{Discussions}

Research was conducted to explore the satisfaction level of employees. Research was developed in Bahawalpur City of Pakistan; private sector was selected to study thoroughly. The aim of the study was to know about the job conditions in developing city. We studied many past researches and from those researches we found these variables: empowerment, rewards, training \& development and working conditions. On the basis of these variables we developed hypotheses which we discussed above. We choose the sample of 200 workers from the private organizations of the concerning city, from which 151 were selected for further analysis.

We have two parts in this research one part discusses the behavior of Top level Management towards empowerment, rewards, training \& development and the next part discusses the level of employee Satisfaction. First we use Top Level Management as independent variable which is effecting empowerment, rewards and Training \& development. In the next part we use Employee Satisfaction as dependent variable 0n rewards, working conditions, empowerment 
and training \& development. After analysis we found that top level management has significant effect on rewards and it contributes more than $49 \%$ in rewards, more than $60 \%$ in training \& development and more than $35 \%$ in empowerment. In the next part only rewards are supporting the employee satisfaction which has significance less than 0.05 and contributes $30 \%$ in employee satisfaction other hypotheses has been rejected.

\section{Conclusions}

Results revealed that in Pakistani environment rewards, appraisal, appreciation and compensation are playing important role in playing satisfaction, rest of the variables has insignificant effect. We concluded that if organizations want to increase the productivity of employees, they have to pay special attention towards rewards. No doubt Pakistani human resources are fighting for basic requirements so the results are close to reality. Since, researchers collected data from 151 respondents; therefore, increase in sample size can generate more generable results.

\section{Research Limitations}

The research is limited in the small city of Pakistan and only private small organizations were selected. If the same research is conducted in metropolitan city, increased in sample size and public \& other big organizations are involved may be the results will be deviated.

\section{References}

Igalens, J. and Roussel, P. (1999), "A French comparative study of the relationships between compensation work motivation and job satisfaction of exempt and non-exempt employees", Working Paper No. 224(96-24), LIRHE, Unicersite Toulouse I, Toulouse.

Brewer, E.W., Lim, D.H. and Cross, M.E. (2008), "Job satisfaction and employee perception of the learning environment in the health care management industry", Journal of Leadership Studies, Vol. 1 No. 4, pp. 37-50.

Ahsan, N., Abdullah, Z., Fie, D.Y.G. and Alam, S.S. (2009), "A study of job stress on job satisfaction among university staff in Malaysia: empirical study", European Journal of Social Sciences, Vol. 8 No. 1, pp. 121-31.

Opkara JO (2002). The Impact Of Salary Differential On Managerial Job Satisfaction. A Study Of The Gender Gap And Its Implications For Management Education And Practice In A Developing Economy. J. Bus. Dev. Nation, 65-92.

Park HJ, Mitsuhashi H, Fey CF, Bjorkman I (2003). The effect of human resource management practices on Japanese MNC subsidiary performance. A practical mediating model. Int. J. Hum. Res. Manage., 14(8): 1391-1406.

Stephen, P.Robbins, Mary Coulter and Neharika Vohra. (2010). Management.USA: publishing as Prentice Hall.

Cunningham, I., Hyman, J. and Baldry, C. (1996), “Empowerment: the power to do what?", Industrial Relations Journal, Vol. 27 No. 2, pp. 143-54 


\section{Macrothink}

International Journal of Human Resource Studies ISSN 2162-3058 2014, Vol. 4, No. 2

Conger, J.A. and Kanungo, R.N. (1988), "The empowerment process: integrating theory and practice", Academy of Management Review, Vol. 13 No. 3, pp. 471-82

Hales, C. and Klidas, A. (1998), "Empowerment in five-star hotels: choice, voice or rhetoric?", International Journal of Contemporary Hospitality Management, Vol. 10 No. 3, pp. $88-95$.

Schneider, B. and Bowen, D.E. (1985), "Employee and customer perceptions of service in banks: replication and extension”, Journal of Applied Psychology, Vol. 70,

pp. 423-33.

Spector, P. (1997), Job Satisfaction, Sage Publications, Thousand Oaks, CA.

Spector, P. and O'Connell, B.J. (1994), “The contribution of personality traits, negative, locus of control and Type A to the subsequent reports of job stressor and job strains", Journal of Occupational and Organizational Psychology, Vol. 67 No. 1, pp. 1-11.

Ellickson. M.C., \& Logsdon, K. (2002). Determinants of job satisfaction of municipal government employees [Electronic version]. Public Personnel Management, 31(3), 343-358.

C.R.Reilly(1991) Organizational Behavior. Annual Review of Psychology, pp. 427- 458

J.P. Wanous and E.E. Lawler (1972) Measurement and Meaning of Job Satisfaction. Journal of Applied Psychology, pp95-105

A.H. Maslow (1954) Motivation and Personality. New York: Harper \& Row.

Kuhlen, R.G. (1963), "Needs, perceived need satisfaction opportunities, and satisfaction with occupation", Journal of Applied Psychology, Vol. XL VII No. 1, pp.

56-64.

Conrad, K.M., Conrad, K.J. and Parker, J.E. (1985), "Job satisfaction among occupational health nurses", Journal of Community Health Nursing, Vol. 2, pp. 161-73.

AL-Hussami M (2008). A Study of nurses' job satisfaction: The relationship to organizational commitment, perceived organizational support, transactional leadership, transformational leadership, and level of education. Eur. J. Sci. Res., 22(2): 286-295.

Mulinge M, Muller CW (1998). Employee Job Satisfaction in Developing Countries: The Case of Kenya. World Dev., 26(12): 2181-2199

Lane KA, Esser J, Holte B, McCusker MA (2010). A study of nurse faculty job satisfaction in community colleges in Florida. Teach. Learn. Nurs., 5: 16-26.

Vidal MES, Valle RS, Aragón BMI (2007). Antecedents of repatriates' job satisfaction and its influence on turnover intentions: Evidence from Spanish repatriated managers. J. Bus. Res., 60: $1272-1281$. 


\section{I Macrothink}

International Journal of Human Resource Studies ISSN 2162-3058 2014, Vol. 4, No. 2

Frye MB (2004). Equity-based compensation for employees. Firm performance and determinants. J. Finan. Res. 27(1): 31-54.

Igalens, J. and Roussel, P. (1999), “A French comparative study of the relationships between compensation work motivation and job satisfaction of exempt and

non-exempt employees", Working Paper No. 224(96-24), LIRHE, Unicersite Toulouse I, Toulouse.

Sokoya SK (2000). Personal Predictors of Job Satisfaction for the Public Sector Manager. Implications for Management Practice and Development in a Developing Economy. J. Business in Developing Nations, available at www.rh.edu/Ismt/jbdnv40.htm.

Nguyen A, Taylor J, Bradley S (2003). Relative Pay and Job Satisfaction. Some New Evidence, MPRA Paper No 1382. Dawson P (1987).Computer Technology and the Job of the First-line Supervisor New Technology. Work Empl., 2(1): 47-59

Brudney JL, Coundrey SE (1993). 'Pay for performance: Explaining the differences in managerial motivation. Public Productivity Manage. Rev., 17(2): 129-144.

Gneezy U, Rustichini A (2000). Pay enough or don’t pay at all. Q. J. Econ., 115: 791-810.

Gardner DG, Dyne LV, Pierce JL (2004). The effects of pay level on organization based self-esteem and performance. A field study. J. Occup.Organ. Psychol., 77: 307-322.

Tessema M, Soeters J (2006). Challenges and prospects of HRM in developing countries. Testing the HRM-performance link in Eritrean civil service. Int. J. Hum. Res. Manage., 17(1): 86-105.

Dawson P (1987).Computer Technology and the Job of the First-line Supervisor New Technology. Work Empl., 2(1): 47-59.

Peccei, R. and Rosenthal, P. (2001), "Delivering customer-oriented behavior through empowerment: an empirical test of HRM assumptions", Journal of Management Studies,

Vol. 38 No. 6, pp. 831-58.

Wilkinson, A. (1998), "Empowerment: theory and practice", Personal Review, Vol. 27 No. 1, pp. 40-56.

Velthouse, B.A. (1990), "Creativity and empowerment: a complementary relationship", Review of Business, Vol. 12, Fall, pp. 13-18.

Thomas, K.W. and Velthouse, B.S. (1990), "Cognitive elements of empowerment", Academy of Management Review, Vol. 15 No. 4, pp. 666-81.

Spreitzer, G.M. (1995), "Psychological empowerment in the workplace: dimensions, measurement and validation", Academy of Management Journal, Vol. 38 No. 5, pp. 1442-65

Rizwan, M., Shahzad, N., Sheikh, Q., Batool, S., Riaz, M. \& Saddique, S. (2013) Variables that Have an Impact on Employee Satisfaction And Turnover Intention, International Journal 
of Research in Commerce, Economics and Management, 3(3), 131-138

Jun, M., Cai, S. and Shin, H. (2006), "TQM practice in maquiladora: antecedents of employee

satisfaction and loyalty”, Journal of Operations Management, Vol. 24, pp. 791-812

Saks, A.M. (1996), "The relationship between the amount and helpfulness of entry training and work outcomes", Human Relations, Vol. 49 No. 4, pp. 429-51

Martensen, A. and Gronholdt, L. (2001), "Using employee satisfaction measurement to improve people management: an adaptation of Kano's quality types", Total Quality Management, Vol. 2 Nos 7/8, pp. 949-57.

Reiner MD, Zhao J (1999). The determinants of job satisfaction among United States Air Force's security police. Rev. Public Personnel Adm., 19(3): 5-18.

Carlan P (2007), The search for job satisfaction. A survey of Alabama policing. Am. J. Criminal Justice, 32 (1-2): 74-86.

Ellickson, M.C. and Logsdon, K. (2001), "Determinants of job satisfaction of municipal government employees", State and Local Government Review, Vol. 33 No. 3, pp. 173-84.

Forsyth CJ, Copes JH (1994), Determinants of job satisfaction among police officers. Int. R. Modern Sociol. 24(1): 109-16

Herzberg, F. (1968), Work and the Nature of Man, World Publishing, New York, NY.

Lavy V (2007). Using performance based pay to improve the quality of teachers. Future Children. 17(1): 87-109.

Rizwan, M., Jaskani, J. H., Ameen, H., Hussain, S., Farooq, R. U., and Omair, M. (2013). Antecedents of Employee Satisfaction and it's impact on Job Turnover, International journal of Management Sciences and Business Research, 2(1), 55-64

Guest DE (2004). Flexible employment contracts, the psychological contract and employee outcomes. An analysis and review of the evidence. Int. J. Manage. Rev., 5/6 (1): 1-19.

Silla I, Gracia F, Peiro JM (2005). Job insecurity and health-related outcomes among different types of temporary workers. Econ. Ind. Democracy, 26: 89-117

Ceylan, A. (1998), "O” rgu” tsel Davranıs, 1n Bireysel Boyutu”, GYTE Publishing No: 2, GYTE Baski ve Fotofilm merkezi, Gebze. 